\title{
MÜZEAL FENOMEN OLARAK FOLKLOR
}

Yegane M. EYVAZOVA*

\section{$\ddot{O} \mathbf{z}$}

Tarihî içeriği, aksiolojik, bilgilendirici seciyesi ile folklor, muzeal fenomen olarak idrak edilmektedir. Bu özelliklerden ileri gelerek bu fenomenin korunmasında müzeleștirme yöntemlerinin uygulamasını güncelleşiyor. Makalede folklorun korunması ile ilgili UNESCO öncelikleri müze bilimleri açısından tahlil edilmiştir.

Anahtar Sözcükler: Folklor, müzeal, koruma, müzeleştirme, halk kültürü.

\section{FOLKLOR AS MUSEUM PHENOMEN}

\begin{abstract}
Absract
Folklore is been perceived as museum phenomen with its historical maintenance, axiological, informative character. Forward from these features coming it actualizes the application of methods museum in the guarding of the same phenomen. In the article priorities of the UNESCO have been involved connected with guarding of the folk-lore to the analysis in the article from context of museum management studies.
\end{abstract}

Keywords: Folklore, muzeal, guarding, museum, people culture.

\section{Giriş:}

Kültürün unsurlarından biri olduğu kabul edilen kültürel miras, zengin yapıya sahip bir sistemdir. Bu sistemde folklorun müstesna yeri vardır. İnsanlık tarihinin en eski katlarından süzülerek modern zamanımıza ulaşan genel mirasın bu yapısı kendiliğinde büyük bir kültürdür. $\mathrm{Bu}$ kültürün değeri ve tekliği öncelikle mensup olduğu sosyal topluluğun kendine özgü yönlerini, yaşam ve düşünce tarzını kendisinde belirtme şekli ile anlatılıyor. İşte bu özellik mevzubahis kültürün 1846 yılında William TOMSON tarafından bilimsel dolaşıma dâhil edilmiş İngilizceden "halk bilgeliği”, "halk bilgisi" anlamlarına gelen "folklor" istlahı ile adlandırılmasını zorunlu kılmıştır. $\mathrm{Bu}$ anlamlar halk manevi kültürünün çeşitli tezahürlerini içeriyor. Çoğu zaman bilimsel kaynaklarda folklor sözlü halk kültürü gibi sunulsa da aslında o daha geniş ölçekli bir fenomendir. Temeli sanatsal halk yaratıcılı̆̆ üzerinde oluşturulan folklor kendisinde halk mimarisi, halk ressamlığı ve sanatın diğer benzer alanlarını da temsil eden bir kültür tipidir. Bu nedenle folklor bileşik ve sentetik bir sanattır. Çünkü folklor eserlerinde sözlü sanat, müzik, tiyatro gibi çeşitli sanat türlerinin unsurları vardır. Tarihî, kültürel olay ve aynı zamanda sosyal bir fenomen olmasından ileri gelerek folkloru öğrenen ayrıca bir alan folklor bilimlinin oluşmasına rağmen o, hem de kendi içeriği ile birçok bilimlerin araştırmasına tabidir.

\footnotetext{
*Doç. Dr.; Azerbaycan Devlet Güzel Sanatlar Üniversitesi, eyvazova.yegane@ mail.ru.
} 
Özellikle geçmişi eski tarihe sahip kültürel anıtlar temelinde öğrenen ve bu yapıların korunması sorunlarını araştırma konusu yapan müze biliminin temel araştırma objelerinden biri folklordur. Folklor kavramının anlaşılması meselesine benzer olarak müze bilimi de çoğu zaman sadece eşya, madde değerlerinin korunması, tebliği sorunlarını öğrenen bilim olarak anlaşılır. Müze biliminin şekillendiği ilk çağlarda bu yaklaşım kabul edilebilir sayılsa da tarihî geçmişe daha geniş açıdan bakış onun daha çağdaş seciyesine ivme kazandırmıştır. Bugün bilimsel fen olarak müze bilimi öğrendiği olayın özünü değil aksiolojik, bilgilendirici belirtisini, başka bir deyişle, değerini önemli argüman sayıyor. Bu açıdan folklor müzeal değere sahip bir fenomendir. Folklorun müzealliğine geçmeden önce "müzeal”in mahiyetini inceleyelim. "Müzeal” deyince müze için önemi olan nesneler öngörülüyor. Bu terimin müze biliminde onayı Çek müze bilimcisi Zbinek STRANSKI'nin gerçekliğe "müze yaklaşımı" tezi ile ilgili olmuştur'. Çek müze bilimcisi çevredeki maddi ve maddi olmayan nesnelerin insanlarda "müze merakı" yaratabilen özelliklerini “müze yaklaşımı”nın ilk safhası olarak değerlendiriyor. "Müze talebi”, “müze merakı", "müze değeri” tüm bunlar müze ilişkisinin başlangıç ögeleridir. Teorik müze biliminin içeriğine dâhil edilmiş müzealliğin morfolojisini ilk kez bu yazar "müze talebi”, "müze değerliliği”" gibi temel kavramlar üzerinde belirlemiştir. Bunların üstü müzeallik, müzelilik - müze bilimi parçalarıdır. Zbinek STRANSKI önerilerinde müze için önemi olan olay, süreçlerin seçimi ve onların belgelenmesinde nesnenin özündeki değerin kavranması olgusunu esas alıyordu². Bununla araştırmacı "müze" kavramını "müzeal mekan" kavramına dâhil ederek kurumsal müzeden daha çok "duvarsız müze"yi tercih etdiğini gösteriyordu. Müzeallik faaliyet alanı gibi idrak edilir. "Faaliyet alanı bakımından, muzeal mekan miras dünyasına özel bir yaklaşımı (yani neyin korunmasının öneminin müzeal açıdan belirlenmesini) karakterize eder”’3. Böylece, tüm bu argümanlar asırlardan asırlara, nesillerden nesillere korunarak daha da zenginleşmiş biçimde gelip ulaşmış folklorun müzeal bir kategori olduğuna hiçbir şüphe bırakmaz. Bu fikrimizi esaslandıran önemli faktörlerden biri folklorun korunması sorunlarının uluslararası düzeyde çözümüne başlanılması olgusudur. UNESCO'nun 1972 yılında Pari’te kabul ettiği "Dünya kültürel ve doğal mirasın korunması Sözleşmesi”nde doğrudan değil dolaylı olarak da olsa halk kültürü tesislerinin müzeleştirilmesi meselesi ön plana geçti ${ }^{4}$. İşte bu sözleşmeden sonra zengin folklor gelenekleri olan tarihî alanların müzekoru durumu adı altında koruma altına alınması geniş kapsamda hayata geçirilmeye başlandı. $\mathrm{Bu}$ taktik artık devletlerin önceliklerinden biri hâline gelmiştir. Örneğin, Azerbaycan'da halk

\footnotetext{
${ }^{1}$ Stranskiy Z.Z .The theory of systems and museology. Stockholm, 1981, p. 26.

${ }^{2}$ Stranskiy Z.Z .The theory of systems and museology. Stockholm, 1981, p. 33.

${ }^{3}$ Ключевые понятия музеологии. ICOM.Brochure, 2012, с. 43.

${ }^{4}$ Mədəni irsin qorunmasına dair normativ hüquqi aktlar toplusu. Bak1, "Elm”, 2001, s. 60-71. 
kültürünün zengin geleneklerine sahip tarihî bölgelerden Şekinin, Lahıcın tarihî işçilik merkezleri ilan edilmesi bugün de aynı mekanlarda folklorun canlı şekilde yaşamasının bir örneği olarak telakki edilmelidir. Mesele şu ki, bu çeşit arazilerde folklorun canlılığı kendini eş zamanlı her şeyde-üretim, ev, arazinin tarihî mimari planlaması, çeşitli içerikli gelenek geleneklerde tezahür ettiriyor. Şeki şehrinin halk mimarisi temelinde koruyup sakladığı tarihî yüzü eski teknolojik geleneklere dayalı ipekçilik sanayi, mutfak kültürü, yahut Lahıcda eski kurallarla faaliyet göstermekte devam eden bakır işletmeleri, arazide yaşayanların giyim kültürü, dügün törenleri $v b$. folklorun korunmasının en elverişli yöntemidir. Bu tür muhafazanın en büyük avantaj1 nüfusun kendisinin bu süreçte etkinlik göstermesi, eski gelenekleri canlandırmak, yaşatmak isteğidir. Elbette, bu sürece devlet, uluslararası kuruluşların desteği, yönlendiriciliği de önemli şartlardandır. İşte tam bu nedenledir ki, uluslararası örgüt olarak UNESCO bu alanda etkinliğini gittikçe geliştirmektedir. Öyle ki, yukarıda adı geçen sözleşmede sadece maddi değerlerin öngörülmesi folklorun en büyük parçası olan maddi olmayan mirasın dikkatten kenarda kalmasına neden olmuştur. $\mathrm{Bu}$ durumu dikkate alarak örgütün 17. oturumunda üye devletlerden birkaçı maddi olmayan mirasın çeşitli yönlerinin, özellikle de folklorun korunması ile ilgili uluslararası normatif belgenin hazırlanması yönünde teşebbüs ileri sürdüler. Çünkü folklorun korunması insanlığın kültürel mirasının zenğinleşmesi ve halkların kültürel özelliklerinin korunmasının en etkili yollarından biridir.

UNESCO Ali Konferans1 1989 Kasım'1nda yapılan 25. oturumunda folklorun da korunması hakkında aşağıdaki yedi bölümden oluşan tavsiye kararı kabul etti:

a) Folklorun da belirlenmesi,

b) Folklorun ortaya çıkarılması,

c) Folklorun korunmas1,

d) Folklorun korunmasının teminat1,

e) Folklorunda yayılmas1,

f) Folklorun muhafazas1,

g) Uluslararası işbirliğgi.

$\mathrm{Bu}$ belgede örgütün üye devletlerine yapılan başvurunun içeriğinin özü aksiolojik açıdan hem tarihi hem sanatsal-estetik hem de sosyal değer taşıyan kültürel mirasın kendi seciyesine göre çok ince ve kırılgan olan bu terkibin müzeal değerinin ön plana çıkarılmasıydı. Folklorun muzeal değeri, öncelikle onun muhafazaya olan talebinin güncelliği ile izah ediliyordu. Çünkü belğede gösterildiği gibi kültürel mirasın diğer kategorilerinden farklı olarak 
folklor küreselleşmenin etkisi sonucunda kaybolup gitme tehlikesi ile karşı karşıyadır. $\mathrm{Bu}$ yetersizliği halletmek amaciyla folklorun, özellikle sözlü halk kültürünün de kendine özgü şekilde müzeleştirilmesi, yani onun korunması için etkin yöntemlerin gerçekleştirilmesi güncellik kazandı. Tavsiyelerde folklorun korunması amacıyla müze tipi işletmelerin, örneğin millî folklor arşivleri, folklor müzeleri ya da mevcut müzeler bünyesinde folklor şubeleri, folklor enstitü ve akademileri oluşturulması, folklor materyallerinin toplanması için profesyonel uzmanların, arşiv uzmanlarının hazırlanması temel öncelikler sırasına dâhil edildi. Azerbaycan Cumhuriyeti’nde bu öncelikler devlet bağımsızlığının tekrar kazanılmasından sonra dikkate alınmaya başladı. Azerbaycan folklorunun korunması amacıyla ülkede 1994 yılında oluşturulan Folklor Sarayı sonradan faaliyetini Folklor Enstitüsü olarak genişletmiştir. Enstitüde folklorun toplanması, yayılması ve mühafazası ile ilgili 10'dan fazla bilimsel şube ve 10'a yakın bilimsel bölme faaliyet gösteriyor. Enstitünün Türk halkları folkloru şubesi Türk halklarının folklor kaynaklarının araştırılması, en değerli folklor yapıların karşılaştırmalı analizi, Türk halklarının folklor metinlerinin arşitiplerinin ve tarihî gelişim aşamalarının belirlenmesi, Türk halkları folklor örneklerinin çeviri ve yayınlarını gerçekleştiriyor. Şubenin temel bilimsel yönü folklorun Türk halkları bağlamında değerlendirilmesinden ibarettir. Yapılan araştırmalarda genel Türk folklor örnekleri objektif rol oynayarak bütünleşiyor. Herhangi bir folklor olayı genel Türk açısından ele alınıyor. Şu anda enstitü özel folklor fonu, folklor müzesi ve folklor kütüphanesinin oluşturulması kapsamındaki çalışmalarını sürdürüyor.

Ülkede folklorun korunması ve yayılması yönünde Azerbaycan Cumhuriyeti Kültür ve Turizm Bakanlığı'nın kabul ettiği “2010-2014 yılları için Azerbaycan'ın Halk Yaratıcılık Başkentleri” projesi temelinde bir dizi bölge sanatsal halk yaratıcılığının korunması ve yayılması yönünde yaptığı isabetli faaliyetlerinden dolayı "Folklor başkenti" ilan edilmiştir. Şeki, Zagatala, Kazak bu statüye layık görülmüştür. Bu gerçekler Azerbaycan Cumhuriyeti’nde folklorun uluslararası standartlar seviyesinde korunmasının teminini yansitıyor. Fakat belirtmek gerekir ki, folklorun uluslararası düzeyde korunmasının teminatı bu tavsiye ve ondan kaynaklanan önceliklerle bitmiyor. Bu alanda UNESCO'nun diğer temel düzenlemelerinden biri de 2003 yılında kabul ettiği "Maddi Olmayan Kültürel Mirasın Korunması Sözleşmesi”dir. Sözleşme korunması öngörülen folklor örneklerinin sınıflandırmasını aşağıdaki gibi belirlemiştir:

a) Maddi olmayan mirasın taşıyıcısı olarak görev yapan dil de dâhil olmak üzere sözlü gelenek ve ifade biçimleri,

b) Yorumculuk sanat,

c) Gelenek, tören ve bayramlar, 
d) Doğa ve evrene ait olan bilgi ve gelenekler,

e) Geleneksel sendikalarla bağlantısı olan bilgi ve alışkanlıklar.

Müze bilimi açısından bu sözleşmenin önceki düzenlemelerden farkı folklor örnekleri için "şaheser" adı altında özel statünün belirlenmesi ile izah edilebilir. Bu durum folklor örneğinin müzeal değerinden ileri gelerek ona özel güvenlik rejiminin uygulanmasını öngörüyor. Folklorun başyapıtlarını tanımlama mekanizması aynı öneme sahip kültürel ve kurumsal kriterlere göre gerçekleştirilir. Şaheseri belirleyen kültürel kriterinin çekirdeğini tarih, sanat, etnoloji, antropoloji, sosyoloji, dilbilim yahut edebiyat açısından olağanüstü evrensel değer oluşturuyor. Evrensel değerin değerlendirilmesi sürecinde folklor örneğinin aşağıdaki yönlerine dikkat yetiriliyor:

1. Folklor örneğinin mevcut toplumun geleneksel kültürüne ya da kültür tarihine gidip çıkan kökleri,

2. Folklor örneğinin mevcut toplumun güncel döneminde sosyal ve kültürel rolü,

3. İşçilik ve ifa tekniği,

4. Folklor örneğinin farklı yönleri,

5. Kaybolma tehlikesi.

Kültürel kriterlere göre tespit edilen şaheser faaliyet planı temelinde muhafazaya alınıyor ve bu kurumsal kriterinin içeriğini sağlar. Etkinlik planına son on yıl içinde folklor örneğinin korunması ve canlandırılması üzere eylemlerin hayata geçirilmesi bu işe desteğin sağlanması dâhildir.

Folklor kültürümüzün en önemli örneği olan Azerbaycan makam sanatı UNESCO'nun “İnsanlığın sözlü ve maddi olmayan kültürel mirasının şaheserleri Listesi” ne dâhil edilmiş, millî âşık sanatı ve Nevruz Bayramı, Çovqan halk oyunu, halı sanatı bu örgütün "İnsanlığın maddi olmayan mirası listesi"ne mevzubahis kültürel ve kurumsal kriterlere göre dâhil edilmiştir. Böylece, yaptı̆̆ımız bu kısa analizden böyle bir tasarruf elde edilebilir: Kendi zengin içeriği ile folklor müzeal bir fenomendir. Folklorun tarihselliği, aksiolojik seciyesi ve bilğilendiriciliği onun müzealliğini kabartan başlıca yönleridir. Bu açılardan düşünülürse folklor muhafazaya ihtiyacı olan kategori olarak kabul edilmelidir ki, bu da onun müze bilimi açısından idrak edilmesini gerektiriyor.

\section{Kaynaklar:}

Mədəni Irsin Qorunmasına Dair Normativ Hüquqi Aktlar Toplusu. (2001). Bak1, "Elm”. STRANSKIY, Z. Z .(1981). The Theory of Systems and Museology. Stockholm. КЛЮЧЕВЫЕ ПОНЯТИЯ МУЗЕОЛОГИИ. (2012). ICОМ, Brochure. 